\title{
Validation of COL11A1/procollagen 11A1 expression in TGF- $\beta 1$-activated immortalised human mesenchymal cells and in stromal cells of human colon adenocarcinoma
}

\author{
José A Galván 1,2,6, Jorge García-Martínez 1,2, Fernando Vázquez-Villa², Marcos García-Ocaña 2,3, \\ Carmen García-Pravia ${ }^{2,4}$, Primitiva Menéndez-Rodríguez ${ }^{4}$, Carmen González-del Rey ${ }^{4}$, Luis Barneo-Serra ${ }^{1,2}$ \\ and Juan R de los Toyos ${ }^{2,5^{*}}$
}

\begin{abstract}
Background: The human COL11A1 gene has been shown to be up-regulated in stromal cells of colorectal tumours, but, so far, the immunodetection of procollagen 11A1, the primary protein product of COL11A1, has not been studied in detail in human colon adenocarcinomas. Some cancer-associated stromal cells seem to be derived from bone marrow mesenchymal cells; the expression of the COL11A1 gene and the parallel immunodetection of procollagen 11A1 have not been evaluated in these latter cells, either.

Methods: We used quantitative RT-PCR and/or immunocytochemistry to study the expression of DES/desmin, VIM/ vimentin, ACTA2/aSMA (alpha smooth muscle actin) and COL11A1/procollagen 11A1 in HCT 116 human colorectal adenocarcinoma cells, in immortalised human bone marrow mesenchymal cells and in human colon adenocarcinoma-derived cultured stromal cells. The immunodetection of procollagen $11 \mathrm{~A} 1$ was performed with the new recently described DMTX1/1E8.33 mouse monoclonal antibody. Human colon adenocarcinomas and non-malignant colon tissues were evaluated by immunohistochemistry as well. Statistical associations were sought between anti-procollagen 11A1 immunoscoring and patient clinicopathological features.

Results: Procollagen 11A1 was immunodetected in human bone marrow mesenchymal cells and in human colon adenocarcinoma-associated spindle-shaped stromal cells but not in colon epithelial or stromal cells of the normal colon. This immunodetection paralleled, in both kinds of cells, that of the other mesenchymalrelated biomarkers studied: vimentin and alpha smooth muscle actin, but not desmin. Thus, procollagen $11 \mathrm{~A} 1^{+}$ adenocarcinoma-associated stromal cells are similar to "activated myofibroblasts". In the series of human colon adenocarcinomas here studied, a high procollagen 11A1 expression was associated with nodal involvement $(p=0.05)$, the development of distant metastases $(p=0.017)$, and advanced Dukes stages $(p=0.047)$.
\end{abstract}

Conclusion: The immunodetection of procollagen $11 \mathrm{~A} 1$ in cancer-associated stromal cells could be a useful biomarker for human colon adenocarcinoma characterisation.

Keywords: Procollagen 11A1, Human bone marrow mesenchymal cells, Cancer-associated stromal cells, Human colon adenocarcinoma

\footnotetext{
* Correspondence: jrtoyos@uniovi.es

${ }^{2}$ Oncology University Institute of the Principality of Asturias (IUOPA), 33006

Oviedo, Spain

${ }^{5}$ Immunology Department, School of Medicine and Health Sciences,

University of Oviedo, c/ Julián Clavería s/n, 33006 Oviedo, Spain

Full list of author information is available at the end of the article
} 


\section{Background}

A wealth of studies have reported that the COL11A1 human gene, coding for the $\alpha 1$ chain of procollagen and mature collagen of type XI, which is an extracellular minor fibrillar collagen, is up-regulated in some human tumours and in mesenchymal-derived tumour cell lines [1-32], as well as in mesenchymal stem cells and osteoblasts [33-35].

Collagen polypeptides are synthesized as procollagens, with the $\mathrm{N}$ - and $\mathrm{C}$-propeptides at the ends of the prototypical collagen triple helix. Upon secretion, the propeptides are excised and then the mature collagen molecules assemble in fibrils.

In tumours, the expression of the COL11A1 gene is currently associated to a fibroblast-like stromal phenotype $[12,19]$ but the origin and nature of the cells which produce procollagen and collagen $11 \mathrm{~A} 1$ remain controversial to some extent [26].

The so-called cancer-associated stromal cells, resulting from the desmoplastic reaction which accompanies the development of human invasive carcinomas, comprise cells of different types, and are at least in part derived from mesenchymal progenitors and local resident cells. It is also well-established that TGF- $\beta 1$ in cancer promotes the activation of cancer-associated stromal cells [36].

For the present study, we set out to verify the expression of the COL11A1 gene, by quantitative RT-PCR in TGF$\beta 1$-exposed epithelial human colorectal HCT 116 cells and Immortalised Human Bone Marrow Mesenchymal Cells (hTERT-HMCs); and the expression of procollagen 11A1 by immunocytochemistry (ICC)/immunohistochemistry (IHC), using the DMTX1/1E8.33 monoclonal antibody (mAb) [37], on those cell cultures as well as on biopsies of human colon adenocarcinomas. Concurrently, we studied the expression of DES/desmin, VIM/ vimentin and $A C T A 2 / \alpha S M A$ (alpha smooth muscle actin) as mesenchymal (myofibroblast)/stromal markers.

Within the $\mathrm{N}$-propeptide of human procollagen 11A1, it is the so-called "variable region", the most divergent amino acid sequence stretch among different procollagens. The DMTX1/1E8.33 mAb recognises an epitope in the YNYGTMESYQTEAPR amino acid stretch within the variable region of human procollagen 11A1 [37].

\section{Methods}

\section{Cell cultures}

Ascorbate is a well-known inducer of the synthesis of some collagens $[38,39]$; thus, to favour the expression of procollagen 11A1, cells were habitually cultured with this supplement. Since TGF- $\beta 1$ levels are increased in the serum of patients with invasive carcinomas [40], we chose to analyse its effects after continued and protracted exposure of cell cultures to this cytokine.
The human colorectal adenocarcinoma HCT 116 (CCL-247) cell line, derived from a primary tumour, was obtained from the American Type Culture Collection (ATCC) and cultured in DMEM, supplemented with $1 \mathrm{mM}$ sodium pyruvate (Biochrom), $2 \mathrm{mM}$ L-glutamine (Biochrom), 1X non-essential amino acids (Biochrom), $10 \%$ foetal bovine serum (Biochrom), and ascorbate 2phosphate $(37.5 \mu \mathrm{g} / \mathrm{ml})$ (Wako Chemicals).

Immortalised Human Bone Marrow Mesenchymal Cells-hTERT (hTERT-HMCs) were obtained from Applied Biological Materials (ABM) Inc., Richmond, BC, Canada (Cat. No. T0523), and grown in T25 ECM-coated flasks in Prigrow II medium (ABM, Cat. No. TM002), with the addition of $10 \%$ foetal bovine serum, $1 \mu \mathrm{M}$ hydrocortisone (Sigma) and ascorbate 2-phosphate $(37.5 \mu \mathrm{g} / \mathrm{ml}$ ) (Wako Chemicals).

For TGF- $\beta 1$ induction, media were further supplemented with $10 \mathrm{ng} / \mathrm{ml}$ of recombinant TGF- $\beta 1$ (Peprotech). The medium was replaced every 3-4 days and the cells were cultured for at least 15 days.

All the cultures were carried out in a humidified atmosphere of $5 \% \mathrm{CO}_{2}$ in air at $37^{\circ} \mathrm{C}$.

Culture passages and cell collections were done with trypsin/EDTA $0.05 \% / 0.02 \%$ (Biochrom). Three different harvests from each cell culture type were obtained; for Q-RT-PCR, fresh cell pellets were kept at $-80^{\circ} \mathrm{C}$.

\section{Colon adenocarcinoma stromal cells isolation and culture}

Fresh human tissue samples were procured after written informed consent of the patients and approval by the Principality of Asturias Ethics Committee of Clinical Research, Oviedo, Spain.

Short-term cultures of colon adenocarcinoma stromal cells were carried out, as previously described [41], from samples of tumoral sites, avoiding necrotic areas. A sample from the operating theatre was directly transferred to a sterile tube containing DMEM culture medium (Gibco, Invitrogen), supplemented with vancomycin $(40 \mu \mathrm{g} / \mathrm{ml})$ and amikacin $(40 \mu \mathrm{g} / \mathrm{ml})$ (Normon Laboratories, Madrid, Spain), and stored for 24 hours at $4^{\circ} \mathrm{C}$.

After three washings with phosphate buffer saline (PBS), the sample was cut into several small fragments. These fragments were first incubated with collagenases (Type I $2 \mathrm{mg} / \mathrm{ml}$, Sigma) for 1.5 hours and then centrifuged to eliminate supernatant; subsequently, the pellet was subjected to a second incubation in trypsin/EDTA for $30 \mathrm{~min}$. After digestion, the cells were again collected in a pellet, resuspended in DMEM culture medium, supplemented with $10 \%$ foetal bovine serum, L-glutamine and penicillin/streptomycin, transferred to T-flasks and cultivated in $5 \% \mathrm{CO}_{2}$ at $37^{\circ} \mathrm{C}$.

Stromal cell cultures were stable up to 5-6 passages before going into senescence. The purity of these stromal 
cell cultures was assessed by morphology and by immunostaining for vimentin.

\section{Q-RT-PCR}

For normalisation of data, quantitative RT-PCR of $D E S$, VIM, ACTA2 and COL11A1 mRNA, and PUM1, RPL10, and GAPDH mRNA was performed using the BioMark ${ }^{\text {TM }}$ HD System of the Fluidigm technology (Fluidigm, San Francisco, USA).

Briefly, total RNA was isolated from pooled cell cultures, kept at $-80^{\circ} \mathrm{C}$, with the RNeasy Mini kit (Qiagen). cDNA was synthesized from 100 ng of RNA from each sample, using the AffinityScript Multiple Temperature cDNA Synthesis kit (Agilent Technologies). A preamplification was carried out, applying the QIAGEN $^{\star}$ Multiplex PCR Kit and the pool of all the 20x TaqMan ${ }^{\circ}$ Gene Expression Assays. Real time Q-PCR reactions were carried out with the TaqMan Universal PCR Master Mix kit (Applied Biosystems). Further details, according to Applied Biosystems' recommendations, are in Table 1.

Data were normalised by applying the $\Delta \mathrm{Ct}$ method, after PCR efficiency corrections. These analyses were performed by Progenika Biopharma, S.A., Derio, Spain.

Three independent samples $(n=3)$ of different cell harvests of each cell type were studied. Data are presented as mean and SEM. For each gene, differences between cell culture expressions were analysed by a two-tailed unpaired $t$-test. A $P$ value $<0.01$ was considered statistically significant.

\section{Immunohistochemistry (IHC)}

For immunohistochemical techniques, a cohort of 51 patients with colon adenocarcinoma and 6 patients diagnosed with incipient bowel infarction were collected from the Archive of the Pathology Department, Asturias Central University Hospital, with the Principality of Asturias Ethics Committee of Clinical Research, Oviedo, Spain, approval for guidelines on ethical procedures. The samples had been fixed with $10 \%$ formaldehyde for $24 \mathrm{~h}$ and embedded in paraffin.

Table 1 Assays selected and PCR conditions for Q-RT-PCR of mRNA analysis

\begin{tabular}{ll}
\hline Gene & Assay ID \\
\hline COL11A1 & Hs01097664_m1 \\
GAPDH & Hs02758991_g1 \\
PUM1 & Hs004472881_m1 \\
RPL10 & Hs00749196_s1 \\
DES & Hs00157258_m1 \\
ACTA2 & Hs00426835_g1 \\
VIM & Hs00185584_m1 \\
\hline PCR conditions
\end{tabular}

PCR conditions were: $50^{\circ} \mathrm{C}-2 \mathrm{~min} ; 95^{\circ} \mathrm{C}-10 \mathrm{~min}$; and 40 amplification cycles: $95^{\circ} \mathrm{C}-15 \mathrm{sec}$ and $60^{\circ} \mathrm{C}-1 \mathrm{~min}$.
Three- $\mu \mathrm{m}$ thick tissue sections were stained with Hematoxylin and Eosin (H\&E) for histological examination. Antigen retrieval was performed by heating in PTLink (DakoCytomation, Denmark) in buffer solution at high $\mathrm{pH}$ for 20 minutes. Endogenous peroxidase activity was blocked with Peroxidase Blocking Reagent (DakoCytomation, Denmark) for 5 minutes. After that, samples were first incubated at $37^{\circ} \mathrm{C}$ with the primary antibodies described in Table 2. Subsequently, the EnVision system (HRP Flex) (DakoCytomation) was applied for 30 minutes at room temperature. Then, the samples were stained with DAB (3-3'-Diaminobenzidine) (DakoCytomation, Denmark) for 10 minutes, counterstained for $10 \mathrm{mi}$ nutes with hematoxylin (DakoCytomation), dehydrated and mounted in Entellan ${ }^{\circledR}$ (Merck, Germany). Finally, the stained tissue sections were studied and photographed (40× objective) under a light microscope (Nikon Eclipse 80i).

\section{Immunocytochemistry (ICC)}

Cells were fixed in 10\% formaldehyde for 10 minutes in the chamber slide (BD Falcon ${ }^{\mathrm{Ts}}$, ref. 354114). Endogenous peroxidase activity was blocked with Peroxidase Blocking Reagent (DakoCytomation, Denmark) for 5 minutes. Permeabilization step was performed adding wash buffer $1 \times$ (DakoCytomation, Denmark) which contains $0.05 \mathrm{~mol} / \mathrm{L}$ Tris/HCl, $0.15 \mathrm{~mol} / \mathrm{L} \mathrm{NaCl}, 0.05 \%$ Tween-20 [41]. Primary antibodies were applied, as described in Table 2, at room temperature. After that, slides were incubated with the EnVision system (HRP Flex) for 10 minutes at room temperature. Then, the samples were visualised with DAB for 5 minutes, and counterstained with hematoxylin for 5 minutes. Finally, the stained slides were dehydrated, mounted, studied and photographed as above.

\section{Immunohistochemistry assessment}

Specimens were assessed by three observers (JAG, CGP and CGR), following these criteria: procollagen 11A1 immunostaining was evaluated according to the cytoplasmatic signal as the product of two parameters: extent of immunoreactivity, which was evaluated in the most densely stained area (hot spot) under the $20 \times$ objective and scored on a $0-3$ scale, according to the proportion of positive fibroblasts: (0) 0\%; (1) <10\%; (2) 10-50\% and (3) >50\%; and granularity in the cytoplasm, evaluated as dispersed vs. confluent ( 1 and 2 points, respectively), with the $40 \times$ objective. Immunoscore values ranged from 0 to 6 . Adjacent non-malignant tissue was used as a negative control.

\section{Statistical analysis}

The experimental results were tested for significance employing the $\chi^{2}$ test (with Yates' correction, when appropriate). The statistical analysis was carried out with 
Table 2 Antibodies used in IHC/ICC analysis

\begin{tabular}{ccccc}
\hline Primary antibodies (species) & Clone & Commercial reference & Dilution & Incubation time (min) \\
\hline Procollagen 11A1 (mAb) & $1 \mathrm{E} 8.33$ & DMTX1/Oncomatrix, Spain & $1: 400$ & 30 \\
Desmin $(\mathrm{mAb})$ & D33 & Dako, Denmark & R-t-U & 20 \\
a-SMA (mAb) & $1 \mathrm{~A} 4$ & Dako, Denmark & R-t-U & 20 \\
Vimentin $(\mathrm{pAb})$ & $\mathrm{C}-20$ & Santa Cruz Biotech, Germany & $1: 600$ & 10 \\
\hline
\end{tabular}

$m A b$ : Mouse monoclonal antibody.

$p A b$ : Rabbit polyclonal antibodies.

$R-t-U$ : Ready-to-Use.

the IBM SPSS 20.0 software package (SPSS, Inc., Chicago, IL). All tests were two-sided and $p<0.05$ values were considered statistically significant.

\section{Results}

Study of human cell cultures

So far, we are not aware of any human colorectal cell line in which the expression of the COL11A1 gene has been reported, but we had observed that primary cultures of bone marrow-derived human mesenchymal cells, expressed COL11A1/procollagen 11A1, especially after long exposure ( $\geq 15$ days) to TGF- $\beta 1$ (data not shown).

We have presently studied the well-known epithelial human colorectal HCT 116 cell line as a negative control for the expression of the mesenchymal DES, VIM, $A C T A 2$ and COL11A1 genes in relation to their expression by cultured immortalised hTERT-HMCs. The expression of the DES, VIM, ACTA2 and COL11A1 genes was analysed by Q-RT-PCR; the immunodetection of desmin, vimentin, $\alpha \mathrm{SMA}$ and procollagen $11 \mathrm{~A} 1$ was performed by ICC.
According to the normalised Q-RT-PCR data we have obtained (Figure 1), TGF- $\beta 1$-activated hTERT-HMCs did not express DES mRNA, but noticeable amounts of VIM, ACTA 2 and COL11A1 mRNA. The corresponding protein expression was confirmed by ICC (Figure 2). An average of $20 \%$ of these cells in cultures exposed to TGF- $\beta 1$ showed a granular pattern of intracytoplasmic immunostaining of procollagen 11A1. None of these markers was expressed by the HCT 116 cells, but certain levels of $D E S$.

\section{Examination of human tissues}

Fifty one paraffin-embedded archival samples of human colon adenocarcinomas were examined by IHC with the DMTX1/1E8.33 mAb; all cases presented adjacent nonmalignant tissue as control. Six cases of incipient bowel infarction were similarly studied. Table 3 shows the characteristics of patients and samples, and their antiprocollagen 11A1 immunoscores, evaluated as described in Methods; as shown, these immunoscores ranged from 0 to 6 . A more detailed description of these characteristics

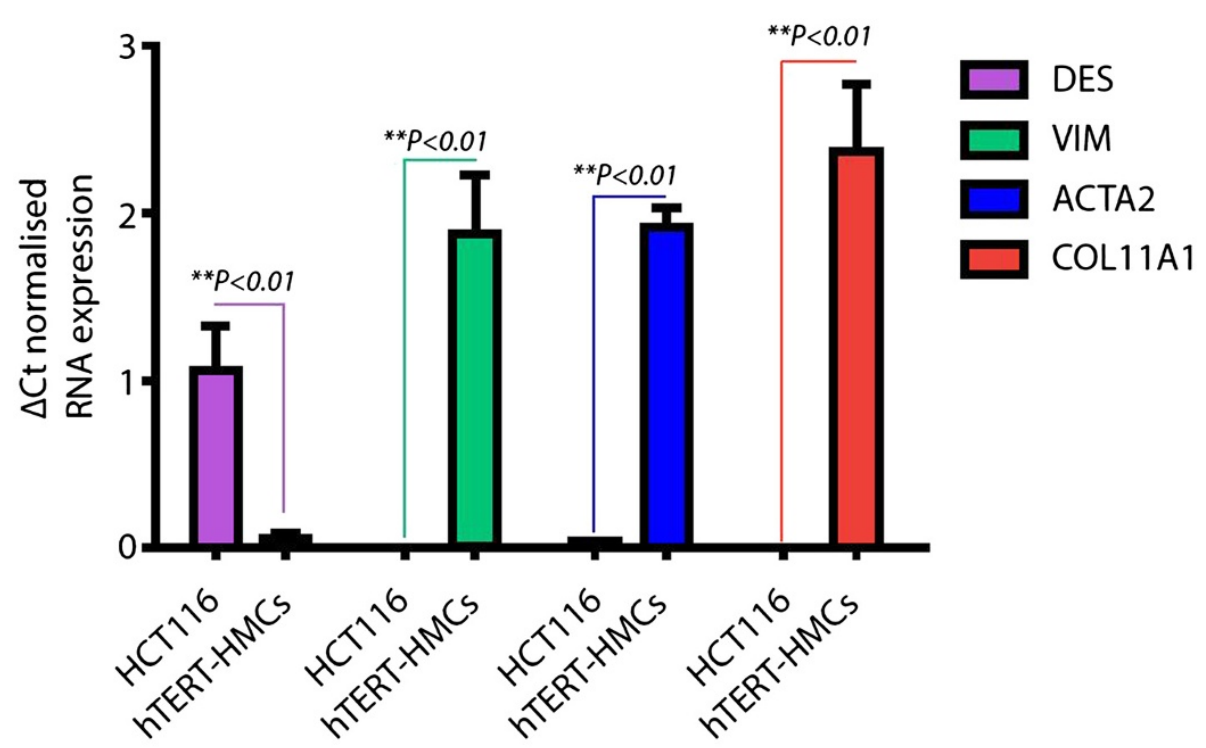

Figure 1 Q-RT-PCR data of DES, VIM, ACTA2 and COL11A1 mRNA expression in cell cultures of the HCT 116 cell line and in immortalised hTERT-HMCs, both after long exposure to ascorbate 2-phosphate and TGF- $\beta 1$. The data were normalised in relation to PUM1, RPL10, and GAPDH mRNA expression ( $\mathrm{n}=3$; mean $\pm \mathrm{SEM}$; ${ }^{*} \mathrm{P}<0.05$, ** $\mathrm{P}<0.01$ ). 

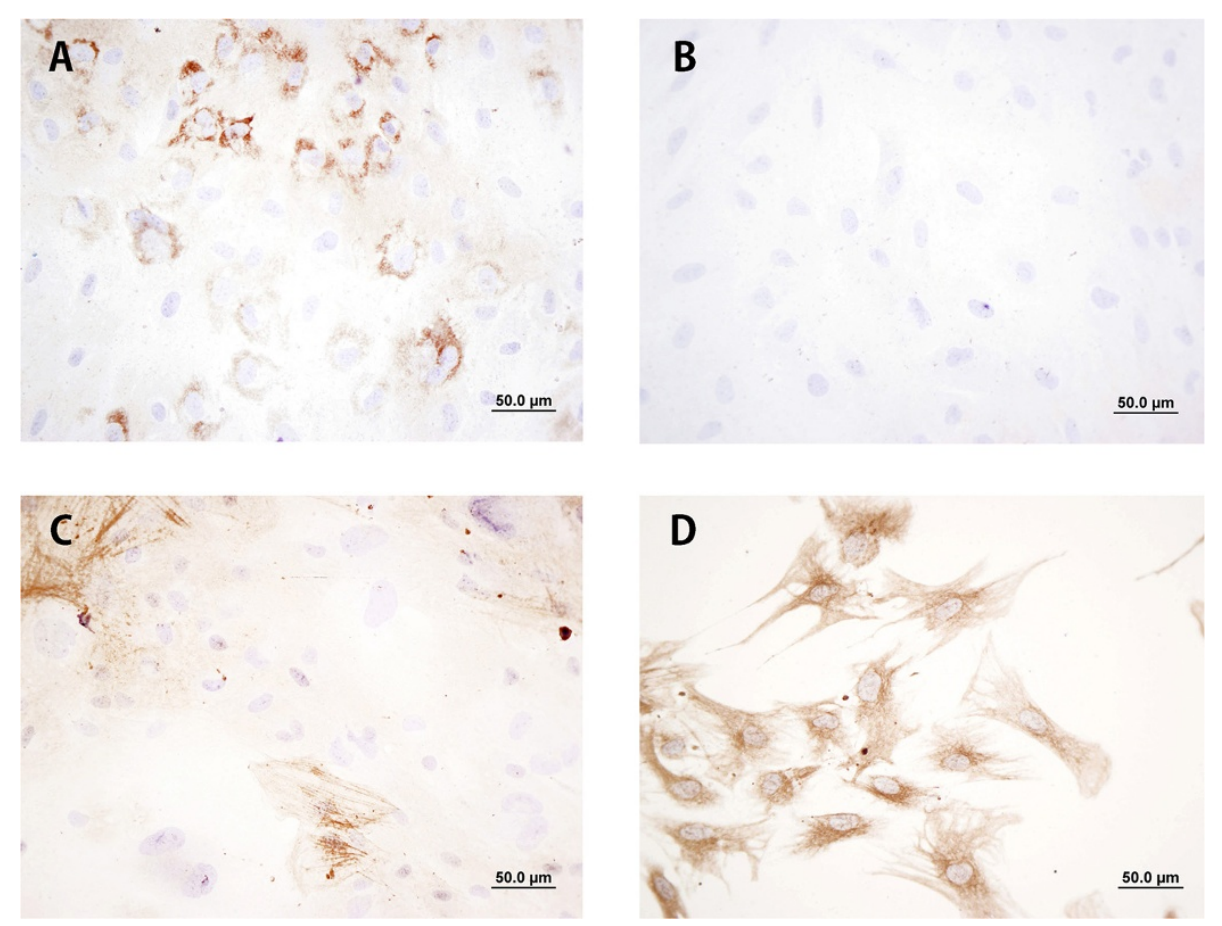

Figure 2 Representative immunostaining of cultured immortalised hTERT-HMCs after long exposure to ascorbate 2-phosphate and TGF- $\beta$ 1. A) Procollagen 11A1 B) Desmin, C) aSMA and D) Vimentin. Scale bar $50 \mu \mathrm{m}(400 \mathrm{x}$ ).

is in Additional file 1. In three of these 51 diagnosed adenocarcinoma cases, no procollagen $11 \mathrm{~A} 1$ staining could be detected, in spite of extensive re-examination. Procollagen $11 \mathrm{~A} 1$ was neither immunodetected in the adjacent nonmalignant tissues nor in the infarction cases.

Figure 3 shows representative procollagen $11 \mathrm{~A} 1 \mathrm{im}$ munostaining patterns (panels A, B, C and D); only a granular cytoplasmic staining of peritumoral spindleshaped fibroblast-like stromal cells was observed. This granularity was either dispersed, with a few granules in the cytoplasm of stromal cells (panel G) or frankly confluent (panel $\mathrm{H}$ ). No staining was observed on specimens of bowel ischemia (panel E) or on non-malignant tissues (panel F).

Figure 4 shows a representative immunostaining of an adenocarcinoma specimen with a procollagen 11A1 immunoscore of 6 . As shown on panel A, only peritumoral stromal cells were stained with the anti-procollagen 11A1 mAb; besides, these cells seemed to be positive for aSMA (C) and vimentin (D), but negative for desmin (B). This immunostaining pattern was reproduced (panels E, F, $\mathrm{G}$ and $\mathrm{H}$ ) in stromal cells cultured from fresh specimens of the same patient.

\section{Association between procollagen 11A1 expression and clinicopathological features}

For statistical purposes, some variables (age at diagnosis, tumour size, anti-procollagen 11A1 immunostaining) were divided into 2 groups, taking the median score value as a cut-off point (Table 4). Patients diagnosed with ischemia were excluded from this analysis.

9/12 patients that had developed distant metastases at diagnosis and 15/27 patients with advanced Dukes stages were associated with high procollagen 11A1 expression ( $p=0.017$ and $p=0.047$, respectively). The same can be observed for 15/26 patients with nodes affected, however, only with a trend towards significance $(p=0.059)$.

\section{Discussion}

We have presently shown, extending our previous observations [42], that procollagen $11 \mathrm{~A} 1$, as a protein expression product of the COL11A1 gene, is immunodetected in stromal cells of human colon adenocarcinoma. By contrast, and contrary to a previous report [15], we have never observed immunodetection of procollagen 11A1 in epithelial cells of normal colon tissue or colon adenocarcinoma with the DMTX1/1E8.33 mAb. This immunodetection was observed in 48 of the 51 cases studied. Three cases (5.9\%), which were classified under the same criteria as the rest of the cases examined as conventional adenocarcinomas with desmoplastic reaction, did not stain; so far, we have not identified in them any characteristics to which this negative immunostaining could be associated. Except for the report of Fischer et al. [1] who did not find either the expression of COL11A in 5 out of 15 (33.3\%) colonic carcinomas analysed, we are not aware 
Table 3 Patient characteristics $(\mathbf{N}=\mathbf{5 1})$ *

\begin{tabular}{|c|c|c|c|}
\hline & & Frecuency $\mathrm{N}$ & (\%) \\
\hline \multirow[t]{2}{*}{ Gender } & Female & 19 & 37.3 \\
\hline & Male & 32 & 62.7 \\
\hline Age (years) & Median (range) & 70 & $(31-85)$ \\
\hline Tumor size $(\mathrm{cm})$ & Median (range) & 3.7 & $\begin{array}{l}(0.5- \\
11)\end{array}$ \\
\hline \multirow[t]{3}{*}{ Localization } & $\begin{array}{l}\text { Ascending } \\
\text { colon }\end{array}$ & 21 & 41.2 \\
\hline & $\begin{array}{l}\text { Descending } \\
\text { colon }\end{array}$ & 8 & 15.7 \\
\hline & Sigmoid & 22 & 43.1 \\
\hline \multirow[t]{3}{*}{ Differentiation } & $\begin{array}{l}\text { Well } \\
\text { differentiated }\end{array}$ & 19 & 37.3 \\
\hline & $\begin{array}{l}\text { Moderately } \\
\text { differentiated }\end{array}$ & 28 & 54,9 \\
\hline & $\begin{array}{l}\text { Poorly } \\
\text { differentiated }\end{array}$ & 4 & 7.8 \\
\hline \multirow[t]{4}{*}{$\mathrm{T}$} & $\mathrm{T} 1$ & 3 & 5,9 \\
\hline & $\mathrm{T} 2$ & 7 & 13.7 \\
\hline & T3 & 28 & 54.9 \\
\hline & T4 & 13 & 25.5 \\
\hline \multirow[t]{2}{*}{$N$} & pNO & 25 & 49.0 \\
\hline & $\mathrm{pN1}$ & 26 & 51.0 \\
\hline \multirow[t]{2}{*}{ M } & MO & 39 & 76.5 \\
\hline & M1 & 12 & 23.5 \\
\hline \multirow[t]{7}{*}{ TNM staging } & । & 8 & 15,7 \\
\hline & $\| A$ & 12 & 23,5 \\
\hline & $\| B$ & 4 & 7,8 \\
\hline & $\| \mathrm{A}$ & 1 & 2,0 \\
\hline & $\| \mathrm{IIB}$ & 9 & 17,6 \\
\hline & IIIC & 5 & 9,8 \\
\hline & IV & 12 & 23,5 \\
\hline \multirow[t]{4}{*}{ Dukes staging } & A & 8 & 15,7 \\
\hline & B & 16 & 31,4 \\
\hline & C & 15 & 29,4 \\
\hline & $\mathrm{D}$ & 12 & 23,5 \\
\hline \multirow{6}{*}{$\begin{array}{l}\text { Anti-procollagen } 11 \mathrm{~A} 1 \\
\text { immunostaining by score }\end{array}$} & 0 & 3 & 5.9 \\
\hline & 1 & 12 & 23.5 \\
\hline & 2 & 13 & 25.5 \\
\hline & 3 & 4 & 7.8 \\
\hline & 4 & 6 & 11.8 \\
\hline & 6 & 13 & 25.5 \\
\hline $\begin{array}{l}\text { Anti-procollagen 11A1 } \\
\text { immunostaining }\end{array}$ & $\operatorname{Low}(\leq 2)$ & 28 & 54.9 \\
\hline (Median =2) & High (>2) & 23 & 45.1 \\
\hline
\end{tabular}

(*) Patients diagnosed with colon adenocarcinoma. Patients diagnosed with ischemia were excluded. of any more studies reporting the percentage of colon adenocarcinomas expressing the COL11A1 gene; this aspect should be studied in detail.

We have very recently reported that procollagen $11 \mathrm{~A} 1^{+}$ cancer-associated stromal cells of pancreatic ductal adenocarcinoma co-express $\alpha \mathrm{SMA}$, and/or vimentin, and/or desmin in different proportions [41]. We have now confirmed, by Q-RT-PCR and IHC/ICC, the stromal expression of human procollagen 11A1 in colon adenocarcinoma. Although not formally proven, procollagen $11 \mathrm{Al}^{+}$colon adenocarcinoma stromal cells, being spindle-shaped, seem to simultaneously express alpha smooth muscle actin and vimentin, but no desmin; these traits confer to them a myofibroblast-like phenotype rather than a pericyte one [43]. While in the desmoplastic component of hepatocellular carcinomas and pancreatic ductal adenocarcinomas there is a significant contribution of desmin + stellate cells, this is not the case in colon adenocarcinomas. As normal resident intestinal myofibroblasts are not immunoreactive to the DMTX1/1E8.33 mAb, these procollagen $11 \mathrm{~A} 1^{+}$ desmin $^{-}$colon adenocarcinoma stromal cells could be a type of "activated myofibroblasts".

We have also shown that a fraction of cultured immortalised HMCs, after long exposure to TGF- $\beta 1$, exhibit a very similar phenotype to the described above for cancerassociated stromal cells. It is intriguing that only as much as $20 \%$ of these cultured cells express procollagen $11 \mathrm{~A} 1$; this aspect warrants further analysis as well as the global genotype and phenotype of procollagen $11 \mathrm{Al}^{+}$cells.

It has been reported that human bone marrow-derived mesenchymal cells may differentiate in vitro to fibroblast/ myofibroblast-like cells under certain conditions, such as coculture with human colon carcinoma cells and TGF- $\beta 1$, or prolonged exposure to conditioned medium from MDA-MB-231 breast cancer cells; these fibroblast/ myofibroblast-like cells are able to promote tumour growth both in vitro and in vivo [36,44-47]. As the phenotype of procollagen $11 \mathrm{~A} 1^{+}$"myofibroblasts" from colon adenocarcinoma resembles that of cultured TGF$\beta 1$-activated human bone marrow mesenchymal cells, all these observations add support to the tenet that at least some cancer-associated stromal cells, such as the procollagen $11 \mathrm{~A}^{+}$ones, could be bone marrow-derived mesenchymal cells. Altogether, we may suggest that procollagen $11 \mathrm{~A} 1$ could be expressed by a more specialized subpopulation among "activated myofibroblasts".

Halsted et al. [14] reported the cytoplasmic, stromal and vascular immunostaining of both normal and malignant human breast tissues with polyclonal antisera to specific regions of $\mathrm{N}$-terminal domains of human procollagen 11A1. Vargas et al. [30] immunodetected collagen 11A1 in the normal epithelium of human breast and Wu et al. [31] performed it in some human ovarian cancer cell lines, after applying another antibody preparation. Moreover, 

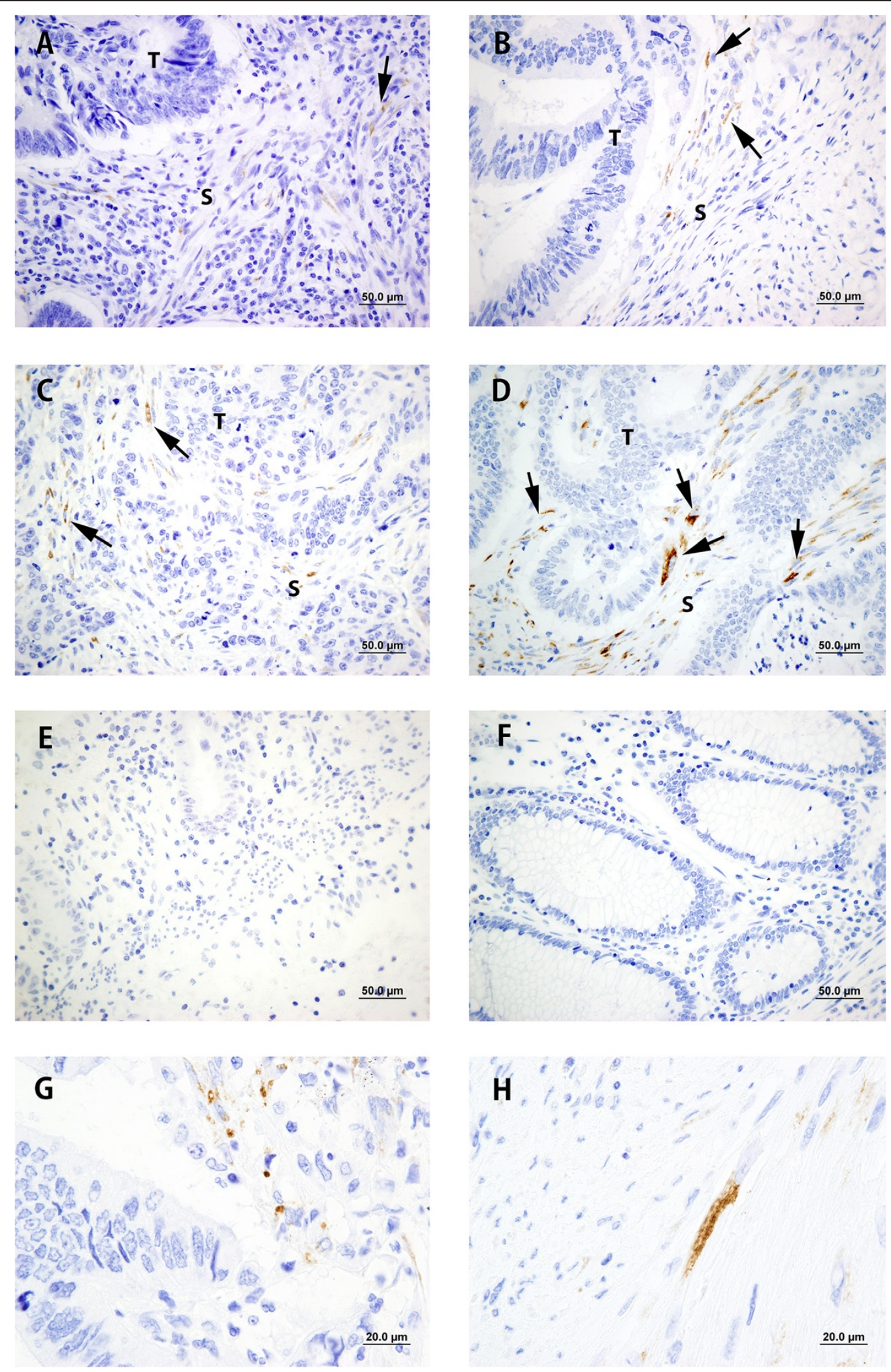

Figure 3 Representative procollagen 11A1 immunostaining in colon adenocarcinoma. A) Score 1, B) Score 2; C) Score 4; D) Score 6. Arrow heads point to stained peritumoral stromal cells. E) Bowel ischemia; F) Non-malignant tissue. Scale bar 50 um (400X). G) Dispersed granularity and H) Confluent granularity. Scale bar $20 \mu \mathrm{m}$ (1000x). 

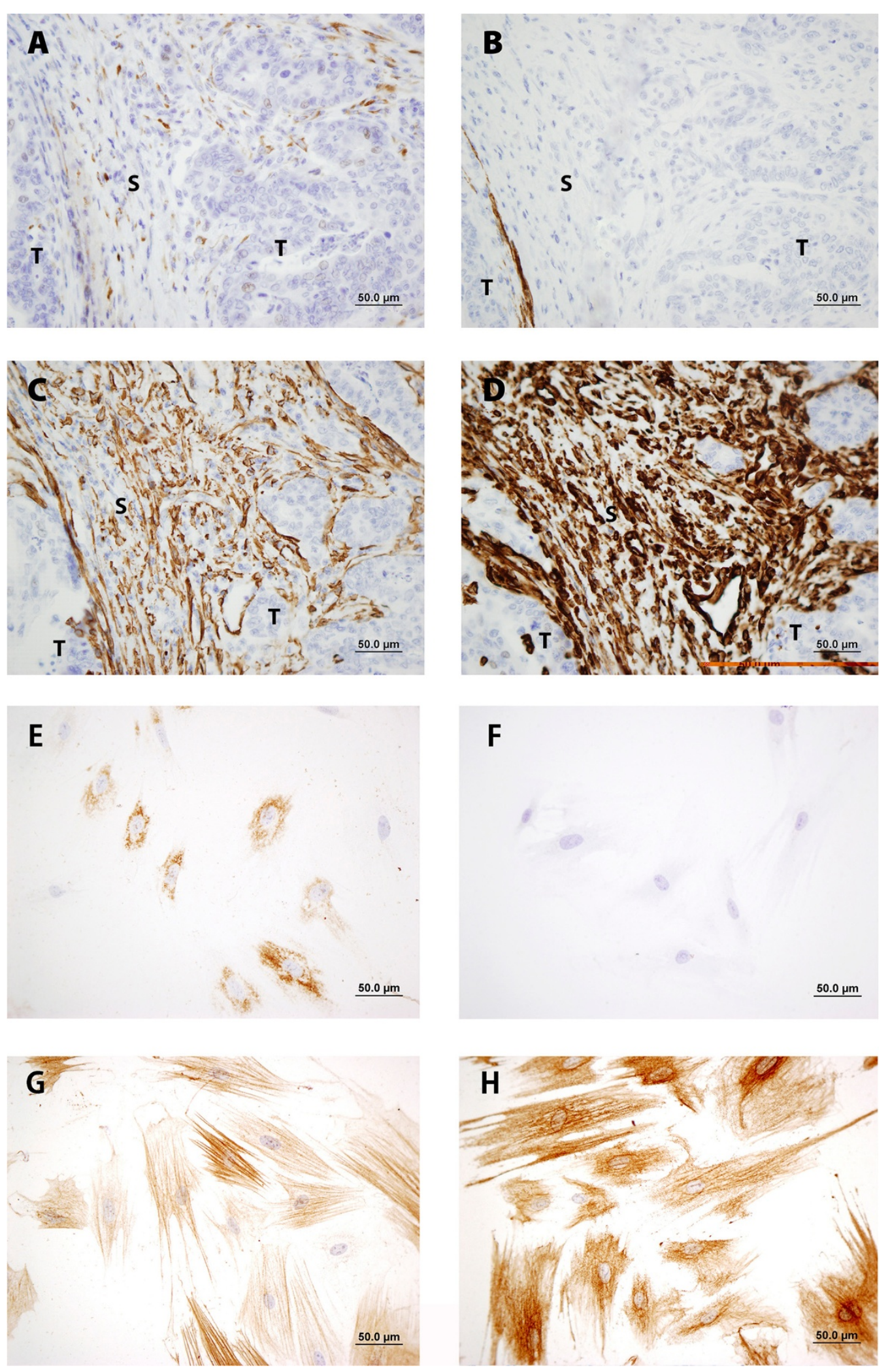

Figure 4 Representative immunostaining of a colon adenocarcinoma: A) Procollagen 11A1 (immunoscore 6), B) Desmin, C) aSMA and D) Vimentin (these images were taken from the same area of serial sections; and of cultured stromal cells from the same case: E) Procollagen 11A1, F) Desmin, G) aSMA and H) Vimentin. Scale bar $50 \mu \mathrm{m}(400 \mathrm{x})$. 
Table 4 Association between procollagen 11A1 expression and clinicopathological features

\begin{tabular}{|c|c|c|c|c|}
\hline & \multicolumn{4}{|c|}{ Anti-procollagen 11A1 immunostaining (Median =2) } \\
\hline & & Low $(\leq 2)$ & High $(>2)$ & $p$ \\
\hline \multirow[t]{2}{*}{ Age (Median 70 years) } & $\leq 70$ years & 13 & 14 & 0.304 \\
\hline & $>70$ years & 15 & 9 & \\
\hline \multirow[t]{2}{*}{ Gender } & Female & 18 & 14 & 0.802 \\
\hline & Male & 10 & 9 & \\
\hline \multirow[t]{3}{*}{ Localization } & Ascending colon & 9 & 12 & 0.260 \\
\hline & Descending colon & 6 & 2 & \\
\hline & Sigmoid & 13 & 9 & 0.200 \\
\hline \multirow[t]{2}{*}{ Tumor size $($ Median = $3.7 \mathrm{~cm})$} & Small $\leq 3.7 \mathrm{~cm}$ & 12 & 14 & \\
\hline & Large $>3.7 \mathrm{~cm}$ & 16 & 9 & 0.370 \\
\hline \multirow[t]{3}{*}{ Differentiation } & Well differentiated & 12 & 7 & \\
\hline & Moderately differentiated & 15 & 13 & \\
\hline & Poorly differentiated & 1 & 3 & \\
\hline \multirow[t]{2}{*}{$\mathbf{T}$} & $\mathrm{T} 1-\mathrm{T} 2$ & 8 & 2 & 0.075 \\
\hline & T3-T4 & 20 & 21 & \\
\hline \multirow[t]{2}{*}{$\mathbf{N}$} & Absent & 17 & 8 & \\
\hline & Present & 11 & 15 & 0.059 \\
\hline \multirow[t]{2}{*}{ M } & Absent & 25 & 14 & \\
\hline & Present & 3 & 9 & 0.017 \\
\hline \multirow[t]{7}{*}{ Stage grouping } & I & 7 & 1 & 0.141 \\
\hline & $\| \mathrm{A}$ & 7 & 5 & \\
\hline & $\| \mathrm{B}$ & 2 & 2 & \\
\hline & $\| \mathrm{A}$ & 1 & 0 & \\
\hline & $\| I \mid B$ & 6 & 3 & \\
\hline & $\| I C$ & 2 & 3 & \\
\hline & IV & 3 & 9 & \\
\hline \multirow[t]{4}{*}{ Dukes staging } & A & 7 & 1 & \\
\hline & B & 9 & 7 & \\
\hline & C & 9 & 6 & 0.047 \\
\hline & D & 3 & 9 & \\
\hline
\end{tabular}

rather contradictory observations have been reported in relation to the kind of cells in which COL11A1 mRNA has been detected. While in situ hybridization studies have spotted its detection only in stromal cells $[1,17]$, another study, based on differentially expressed gene analyses by GeneChip hybridization, has pointed to the over-expression of COL11A1 mRNA in tumour epithelia [13]; very recently, Cheon et al. [48] have reported, also through in situ hybridization and immunohistochemistry with the DMTX1/1E8.33 mAb of serous ovarian cancer, that "COL11A1 expression was confined to intra/peritumoral stromal cells and rare foci of tumor epithelial cells".

In our experience, the immunodetection of procollagen 11A1 with the DMTX1/1E8.33 mAb has never been observed in normal epithelial, vascular or stromal cells but in cancer-associated stromal cells; immunochemistry discrepancies between our observations and those above mentioned may be attributed to the different fine specificity of the applied antibody preparations. Besides this, transcription profiling studies of human colon biopsies obtained from active and inactive areas of ulcerative colitis and Crohn's disease, compared with samples from infectious colitis and healthy controls, have shown that there are no differences in the expression levels of the COL11A1 gene between any of the above referred to conditions [49-53]. COL11A1/procollagen 11A1 expression is mostly absent in benign inflammatory processes such as breast sclerosing adenosis [16,54], chronic pancreatitis [41], and diverticulitis (our own observations; data not shown), and is rather low in familial adenomatosis polyposis adenomas [1,2]. Thus, the in vivo up-regulation 
of the COL11A1 gene may be considered as a biomarker of cancer-associated stromal cells.

In this study, high procollagen 11A1 immunostaining was associated with clinicopathological variables such as lymph node involvement, advanced Dukes stages and presence of distant metastases. These results go according to the role of COL11A1 in promoting carcinoma aggressiveness and progression [11,17,20,30,31,48,55-57].

\section{Conclusions}

Based on its high specificity, our observations stress once more the usefulness of the DMTX1/1E8.33 mAb for cancer research, and the clinical significance of procollagen $11 \mathrm{~A} 1$ as a very valuable biomarker to characterise cancerassociated stromal cells and to evaluate human colon adenocarcinomas.

\section{Additional file}

\section{Additional file 1: Detailed description of patients and their}

clinicopathological characteristics.

\section{Abbreviations}

HMCs: Human mesenchymal cells; hTERT-HMCs: Immortalised hTERT- human bone marrow mesenchymal cells; ICC: Immunocytochemistry; IHC: Immunohistochemistry; mAb: Monoclonal antibody; pAb: Polyclonal antibodies; H\&E: Hematoxylin and eosin; PBS: Phosphate-buffered saline; DAB: 3-3'-Diaminobenzidine.

\section{Competing interests}

The authors declare that they have no competing interests.

\section{Authors' contributions}

JAG carried out immunostainings, photographs and statistical analyses. The immunostainings were evaluated by JAG, CGP and CGR, and supervised by CGP and PMR. JGM isolated and cultured tumour stromal cells. FW and MGO carried out other cell cultures. All authors discussed, read and approved the final manuscript. CGP, PMR, LBS, and JRT contributed equally to this study as senior authors.

\section{Acknowledgements}

The authors thank Inti Zlobec for the critical reading of the manuscript and helpful comments. The excellent technical assistance of Laura SuárezFernández is greatly acknowledged.

This research has been co-financed by European Union ERDF Funds; by the INNPACTO-ONCOPAN IPT-010000-2010-31 Project; by the FISS-09-PS09/01911 Project, Ministry of Science and Innovation, Spain; by the FC-11-PC10-23, FICYT Project, Axe 1 of the 2007-2013 ERDF Operational Framework Programme of the Principality of Asturias, Spain; and by Oncomatrix, S.L. Derio, Spain

\section{Author details}

'Surgery Department, School of Medicine and Health Sciences, University of Oviedo, 33006 Oviedo, Spain. ${ }^{2}$ Oncology University Institute of the Principality of Asturias (IUOPA), 33006 Oviedo, Spain. ${ }^{3}$ Preparative Biotechnology Unit, Technical-Scientific Services, University of Oviedo, 33006 Oviedo, Spain. ${ }^{4}$ Pathological Anatomy Service, Asturias Central University Hospital (HUCA), 33006 Oviedo, Spain. ${ }^{5}$ Immunology Department, School of Medicine and Health Sciences, University of Oviedo, c/ Julián Clavería s/n, 33006 Oviedo, Spain. ' Present address: Translational Research Unit (TRU), Institute of Pathology, University of Bern, Bern, Switzerland.
}

Received: 29 April 2014 Accepted: 12 November 2014 Published: 23 November 2014

\section{References}

1. Fischer H, Stenling R, Rubio C, Lindblom A: Colorectal carcinogenesis is associated with stromal expression of COL11A1 and COL5A2. Carcinogenesis 2001, 22:875-878. doi:10.1093/carcin/22.6.875.

2. Fischer H, Salahshor S, Stenling R, Björk J, Lindmark G, Iselius L, Rubio C, Lindblom A: COL11A1 in FAP polyps and in sporadic colorectal tumors. BMC Cancer 2001, 1:17 [http://www.biomedcentral.com/1471-2407/1/17]

3. Wang KK, Liu N, Radulovich N, Wigle DA, Johnston MR, Shepherd FA, Minden MD, Tsao MS: Novel candidate tumor marker genes for lung adenocarcinoma. Oncogene 2002, 21:7598-7604.

4. Xu SH, Qian L, Mou HZ, Zhu CH, Zhou XM, Liu XL, Chen Y, Bao WY: Difference of gene expression profiles between esophageal carcinoma and its pericancerous epithelium by gene chip. World I Gastroenterol 2003, 9:417-422.

5. Sok JC, Kuriakose MA, Mahajan VB, Pearlman AN, DeLacure MD, Chen FA: Tissue-specific gene expression of head and neck squamous cell carcinoma in vivo by complementary DNA microarray analysis. Arch Otolaryngol Head Neck Surg 2003, 129:760-770.

6. Schmalbach CE, Chepeha DB, Giordano TJ, Rubin MA, Teknos TN, Bradford CR, Wolf GT, Kuick R, Misek DE, Trask DK, Hanash S: Molecular profiling and the identification of genes associated with metastatic oral cavity/ pharynx squamous cell carcinoma. Arch Otolaryngol Head Neck Surg 2004, 130:295-302.

7. Croner RS, Foertsch T, Brueckl WM, Guenther K, Siebenhaar R, Stremmel C, Matzel KE, Papadopoulos T, Kirchner T, Behrens J, Klein-Hitpass L, Stuerzl M, Hohenberger W, Reingruber B: Common denominator genes that distinguish colorectal carcinoma from normal mucosa. Int $J$ Colorectal Dis 2005, 20:353-362.

8. Barneo L, del Amo J, García-Pravia C, de los Toyos JR, Pérez-Basterrechea M, González-Pinto I, Vazquez L, Miyar A, Simón L: Identification of specific genes by microarrays, validation and use of polyclonal antibodies in pancreatic cancer: preliminary results. In 41 st Congress of the European Society for Surgical Research-ESSR 2006. Edited by Vollmar B. Bologna, Italy: Medimond, International Proceedings; 2006:27-35.

9. del Amo-lribarren J: Identificación de marcadores para diagnóstico diferencial y potenciales dianas terapéuticas en adenocarcinoma ductal de páncreas mediante herramientas genómicas, PhD thesis. Universidad del País Vasco, Genetics, Physical Anthropology and Animal Physiology Department; 2006.

10. Chong IW, Chang MY, Chang HC, Yu YP, Sheu CC, Tsai JR, Hung JY, Chou SH, Tsai MS, Hwang JJ, Lin SR: Great potential of a panel of multiple hMTH1, SPD, ITGA11 and COL11A1 markers for diagnosis of patients with non-small cell lung cancer. Oncol Rep 2006, 16:981-988.

11. Vecchi M, Nuciforo P, Romagnoli S, Confalonieri S, Pellegrini C, Serio G, Quarto M, Capra M, Roviaro GC, Contessini Avesani E, Corsi C, Coggi G, Di Fiore PP, Bosari S: Gene expression of early and advanced gastric cancer. Oncogene 2007, 26:4284-4294.

12. Pilarsky C, Ammerpohl O, Sipos B, Dahl E, Hartmann A, Wellmann A, Braunschweig T, Löhr M, Jesenofsky R, Friess H, Wente MN, Kristiansen G, Jahnke B, Denz A, Rückert F, Schackert HK, Klöppel G, Kalthoff H, Saeger HD, Grützmann R: Activation of Wnt signalling in stroma from pancreatic cancer identified by gene expression profiling. J Cell Mol Med 2008, 12:2823-2835

13. Badea L, Herlea V, Dima SO, Dumitrascu T, Popescu I: Combined gene expression analysis of whole-tissue and microdissected pancreatic ductal adenocarcinoma identifies genes specifically overexpressed in tumor epithelia. Hepatogastroenterology 2008, 55:2016-2027.

14. Halsted KC, Bowen KB, Bond L, Luman SE, Jorcyk CL, Fyffe WE, Kronz JD, Oxford JT: Collagen alpha1(XI) in normal and malignant breast tissue. Mod Pathol 2008, 21:1246-1254.

15. Bowen KB, Reimers AP, Luman S, Kronz JD, Fyffe WE, Oxford JT: Immunohistochemical localization of collagen type XI alpha1 and alpha2 chains in human colon tissue. J Histochem Cytochem 2008, 56:275-283.

16. Fuentes-Martínez N: Colágeno 11: Nuevo marcador en el cáncer de mama, $\mathrm{PhD}$ thesis. Universidad de Oviedo, Surgery and Medical Surgical Specialities Department; 2009

17. Zhao Y, Zhou T, Li A, Yao H, He F, Wang L, Si J: A potential role of collagens expression in distinguishing between premalignant and malignant lesions in stomach. Anat Rec 2009, 292:692-700.

18. An JH, Lee SY, Jeon JY, Cho KG, Kim SU, Lee MA: Identification of gliotropic factors that induce human stem cell migration to malignant tumor. J Proteome Res 2009, 8:2873-2881. 
19. Erkan M, Weis N, Pan Z, Schwager C, Samkharadze T, Jiang X, Wirkner U, Giese NA, Ansorge W, Debus J, Huber PE, Friess H, Abdollahi A, Kleeff J: Organ-, inflammation- and cancer specific transcriptional fingerprints of pancreatic and hepatic stellate cells. Mol Cancer 2010, 9:88 [http://www. molecular-cancer.com/content/9/1/88]

20. Kim H, Watkinson J, Varadan V, Anastassiou D: Multi-cancer computational analysis reveals invasion-associated variant of desmoplastic reaction involving INHBA, THBS2 and COL11A1. BMC Med Genomics 2010, 3:51 [http://www.biomedcentral.com/1755-8794/3/51]

21. Pavlides S, Tsirigos A, Vera I, Flomenberg N, Frank PG, Casimiro MC, Wang C, Pestell RG, Martinez-Outschoorn UE, Howell A, Sotgia F, Lisanti MP: Transcriptional evidence for the "Reverse Warburg Effect" in human breast cancer tumor stroma and metastasis: similarities with oxidative stress, inflammation, Alzheimer's disease, and "Neuron-Glia Metabolic Coupling". Aging (Albany NY) 2010, 2:185-199.

22. Chernov AV, Baranovskaya S, Golubkov VS, Wakeman DR, Snyder EY, Williams R, Strongin AY: Microarray-based transcriptional and epigenetic profiling of matrix metalloproteinases, collagens, and related genes in cancer. J Biol Chem 2010, 285:19647-19659.

23. Wilkerson MD, Yin X, Hoadley KA, Liu Y, Hayward MC, Cabanski CR, Muldrew K, Miller CR, Randell SH, Socinski MA, Parsons AM, Funkhouser WK, Lee CB, Roberts PJ, Thorne L, Bernard PS, Perou CM, Hayes DN: Lung squamous cell carcinoma mRNA expression subtypes are reproducible, clinically important and correspond to different normal cell types. Clin Cancer Res 2010, 16:4864-4875. doi:10.1158/1078-0432.CCR-10-0199.

24. Hajdu M, Singer S, Maki RG, Schwartz GK, Keohan ML, Antonescu CR: IGF2 over-expression in solitary fibrous tumours is independent of anatomical location and is related to loss of imprinting. J Pathol 2010, 221:300-307.

25. Planche A, Bacac M, Provero P, Fusco C, Delorenzi M, Stehle JC, Stamenkovic I: Identification of prognostic molecular features in the reactive stroma of human breast and prostate cancer. PLoS One 2011, 6:e18640. doi:10.1371/journal.pone.0018640.

26. Anastassiou D, Rumjantseva V, Cheng W, Huang J, Canoll PD, Yamashiro DJ, Kandel JJ: Human cancer cells express slug-based epithelialmesenchymal transition gene expression signature obtained in vivo. BMC Cancer 2011, 11:529 [http://www.biomedcentral.com/1471-2407/11/529]

27. Navab R, Strumpf D, Bandarchi B, Zhu CQ, Pintilie M, Ramnarine VR, Ibrahimov E, Radulovich N, Leung L, Barczyk M, Panchal D, To C, Yun JJ, Der S, Shepherd FA, Jurisica I, Tsao MS: Prognostic gene-expression signature of carcinoma-associated fibroblasts in non-small cell lung cancer. Proc Natl Acad Sci U S A 2011, 108:7160-7165. doi:10.1073/pnas.1014506108.

28. Lascorz J, Hemminki K, Försti A: Systematic enrichment analysis of gene expression profiling studies identifies consensus pathways implicated in colorectal cancer development. J Carcinog 2011, 10:7. doi:10.4103/14773163.78268

29. Seemann L, Shulman J, Gunaratne GH: A robust topology-based algorithm for gene expression profiling. ISRN Bioinformatics 2012, Article ID 381023. doi:10.5402/2012/381023.

30. Vargas AC, McCart Reed AE, Waddell N, Lane A, Reid LE, Smart CE, Cocciardi S, da Silva L, Song S, Chenevix-Trench G, Simpson PT, Lakhani SR: Gene expression profiling of tumour epithelial and stromal compartments during breast cancer progression. Breast Cancer Res Treat 2012, 135:153-165. doi:10.1007/s10549-012-2123-4.

31. Wu YH, Chang TH, Huang YF, Huang HD, Chou CY: COL11A1 promotes tumor progression and predicts poor clinical outcome in ovarian cancer. Oncogene 2014, 33:3432-3440. doi:10.1038/onc.2013.307.

32. Gene expression atlas- summary for COL11A1 (Homo sapiens). [http://www.ebi.ac.uk/gxa/gene/ENSG00000060718]

33. Boshoff C, Bryson K, Clements MO, Trotter MW, Cellek S, Elliman SJ: Transcription profiling of two populations of non-hematopoietic stem cells (MSC and MAPC) isolated from human bone marrow. ArrayExpress: E-MEXP-466. [http://www.ebi.ac.uk/arrayexpress/experiments/EMEXP-466/]

34. Grundberg E, Brändström H, Lam KC, Gurd S, Ge B, Harmsen E, Kindmark A Ljunggren O, Mallmin H, Nilsson O, Pastinen T: Systematic assessment of the human osteoblast transcriptome in resting and induced primary cells. Physiol Genomics 2008, 33:301-311.

35. Kao L-P, Yu S-L, Singh S, Wang K-H, Kao A-P, Li SS: Comparative profiling of mRNA and microRNA expression in human mesenchymal stem cells derived from adult adipose and lipoma tissues. Open Stem Cell J 2009, 1:1-9. doi:10.2174/1876893800901010001.
36. Polanska UM, Orimo A: Carcinoma-associated fibroblasts: non-neoplastic tumour-promoting mesenchymal cells. J Cell Physiol 2013, 228:1651-1657. doi:10.1002/jcp.24347.

37. García-Ocaña M, Vázquez F, García-Pravia C, Fuentes-Martínez N, MenéndezRodríguez P, Fresno-Forcelledo F, Barneo-Serra L, Del Amo-lribarren J, Simón-Buela L, De Los Toyos JR: Characterization of a novel mouse monoclonal antibody, clone 1E8.33, highly specific for human procollagen $11 \mathrm{~A} 1$, a tumor-associated stromal component. Int J Oncol 2012, 40:1447-1454. doi:10.3892/ijo.2012.1360

38. Hering TM, Kollar J, Huynh TD, Varelas JB, Sandell LJ: Modulation of extracellular matrix gene expression in bovine high-density chondrocyte cultures by ascorbic acid and enzymatic resuspension. Arch Biochem Biophys 1994, 314:90-98.

39. Ronzière MC, Farjanel J, Freyria AM, Hartmann DJ, Herbage D: Analysis of types I, II, III, IX and XI collagens synthesized by fetal bovine chondrocytes in high-density culture. Osteoarthritis Cartilage 1997, 5:205-214

40. Elliott $\mathrm{RL}$, Blobe $\mathrm{GC}$ : Role of transforming growth factor Beta in human cancer. J Clin Oncol 2005, 23:2078-2093.

41. García-Pravia C, Galván JA, Gutiérrez-Corral N, Solar-García L, García-Pérez E, García-Ocaña M, Del Amo-|ribarren J, Menéndez-Rodríquez P, García-García J, de los Toyos JR, Simón-Buela L, Barneo L: Overexpression of COL11A1 by cancer-associated fibroblasts: clinical relevance of a stromal marker in pancreatic cancer. PLoS One 2013, 8:e78327. doi:10.1371/journal. pone.0078327.

42. Cueva-Cayetano R, Galvan-Hernandez JÁ, Suarez-Fernandez L, MenendezRodriguez MP, Garcia-Pravia C, Barneo L: Preliminary analysis of collagen, type $\mathrm{Xl}$, alpha 1 (COL11A1), inhibin alpha (INHBA) and secreted protein acidic and rich in cysteine (SPARC, osteonectin) as potential markers of colon cancer [abstract]. Brit J Surg 2013, 100(Suppl. 1):7.

43. Mifflin RC, Pinchuk IV, Saada JI, Powell DW: Intestinal myofibroblasts: targets for stem cell therapy. Am J Physiol Gastrointest Liver Physiol 2011, 300:G684-G696. doi:10.1152/ajpgi.00474.2010.

44. Emura M, Ochiai A, Horino M, Arndt W, Kamino K, Hirohashi S: Development of myofibroblasts from human bone marrow mesenchymal stem cells cocultured with human colon carcinoma cells and TGF beta 1. In Vitro Cell Dev Biol Anim 2000, 36:77-80.

45. Karnoub AE, Dash AB, Vo AP, Sullivan A, Brooks MW, Bell GW, Richardson AL, Polyak K, Tubo R, Weinberg RA: Mesenchymal stem cells within tumour stroma promote breast cancer metastasis. Nature 2007, 449:557-563.

46. ArrayExpress Experiment E-GEOD-9764: Transcription profiling of human mesenchymal stem cells reveals carcinoma associated fibroblast like differentiation. [http://www.ebi.ac.uk/arrayexpress/ experiments/E-GEOD-9764]

47. Mishra PJ, Mishra PJ, Humeniuk R, Medina DJ, Alexe G, Mesirov JP, Ganesan S, Glod JW, Banerjee D: Carcinoma-associated fibroblast-like differentiation of human mesenchymal stem cells. Cancer Res 2008, 68:4331-4339. doi:10.1158/ 0008-5472.CAN-08-0943.

48. Cheon DJ, Tong Y, Sim MS, Dering J, Berel D, Cui X, Lester J, Beach JA, Tighiouart M, Walts AE, Karlan BY, Orsulic S: A collagen-remodeling gene signature regulated by TGF- $\beta$ signaling is associated with metastasis and poor survival in serous ovarian cancer. Clin Cancer Res 2014, 20:711-723. doi:10.1158/1078-0432.CCR-13-1256.

49. ArrayExpress Experiment E-GEOD-6731: Transcription profiling of human colon biopsies obtained from patients with ulcerative colitis, Crohn's disease vs. normal to identify pathogenic processes underlying these disease subtypes. [http://www.ebi.ac.uk/arrayexpress/experiments/E-GEOD-6731]

50. Wu F, Dassopoulos T, Cope L, Maitra A, Brant SR, Harris ML, Bayless TM, Parmigiani G, Chakravarti S: Genome-wide gene expression differences in Crohn's disease and ulcerative colitis from endoscopic pinch biopsies: insights into distinctive pathogenesis. Inflamm Bowel Dis 2007, 13:807-821

51. ArrayExpress Experiment E-TABM-118: Transcription profiling of biopsies from the descending colon of Crohn's disease patients. [http://www.ebi. ac.uk/arrayexpress/experiments/E-TABM-118/]

52. Csillag C, Nielsen $\mathrm{OH}$, Borup R, Nielsen FC, Olsen J: Clinical phenotype and gene expression profile in Crohn's disease. Am J Physiol Gastrointest Liver Physiol 2007, 292:G298-G304

53. ArrayExpress Experiment E-GEOD-1152: Transcription profiling of human ileum and colonic tissues from patients with Crohns disease or ulcerative colitis. [http://www.ebi.ac.uk/arrayexpress/experiments/E-GEOD-1152]. 
54. Fuentes-Martínez N, García-Pravia C, García-Ocaña M, Menéndez-Rodríguez P, Del Amo J, Suárez-Fernández L, Galván JA, De Los Toyos JR, Barneo L: Overexpression of proCOL11A1 as a stromal marker of breast cancer. Histol Histopathol 2014, [Epub ahead of print].

55. Schuetz CS, Bonin M, Clare SE, Nieselt K, Sotlar K, Walter M, Fehm T, Solomayer E, Riess O, Wallwiener D, Kurek R, Neubauer HJ: Progressionspecific genes identified by expression profiling of matched ductal carcinomas in situ and invasive breast tumors, combining laser capture microdissection and oligonucleotide microarray analysis. Cancer Res 2006, 66:5278-5286.

56. Lee S, Stewart S, Nagtegaal I, Luo J, Wu Y, Colditz G, Medina D, Allred DC: Differentially expressed genes regulating the progression of ductal carcinoma in situ to invasive breast cancer. Cancer Res 2012 72:4574-4586. doi:10.1158/0008-5472.CAN-12-0636.

57. Castellana B, Escuin D, Peiró G, Garcia-Valdecasas B, Vázquez T, Pons C Pérez-Olabarria M, Barnadas A, Lerma E: ASPN and GJB2 are implicated in the mechanisms of invasion of ductal breast carcinomas. J Cancer Educ 2012, 3:175-183. doi:10.7150/jca.4120.

doi:10.1186/1471-2407-14-867

Cite this article as: Galván et al:: Validation of COL11A1/procollagen

$11 \mathrm{~A} 1$ expression in TGF- $\beta 1$-activated immortalised human

mesenchymal cells and in stromal cells of human colon

adenocarcinoma. BMC Cancer 2014 14:867.

\section{Submit your next manuscript to BioMed Central and take full advantage of:}

- Convenient online submission

- Thorough peer review

- No space constraints or color figure charges

- Immediate publication on acceptance

- Inclusion in PubMed, CAS, Scopus and Google Scholar

- Research which is freely available for redistribution 